7. Стандарт вищої освіти України. Рівень вищої освіти другий (магістерський) галузі знань 07 "Управління та адміністрування", спеціальності 073 "Менеджмент" [Електронний ресурс] // Міністерство освіти і науки України: [сайт]. - Режим доступу: (http://www.management.com.ua/ books/view-books.php?id=22)

References

1. Zhylenko M. V. Otsinka efektyvnosti upravlins'koyi diyal'nosti kerivnyka zakladu vyshchoyi osvity / M.V. Zhylenko // Visnyk Kyyivs'koho natsional'noho universytetu imeni Tarasa Shevchenka. - Pedahohika. - 2018. - № 1 (7). - S. 11-14

2. Zhylenko M. V. Vykorystannya pryntsypiv neyrolinhvistychnoho prohramuvannya pry pidhotovtsi menedzheriv dlya osvitn'oyi sfery / M. V. Zhylenko // Visnyk Kyyivs'koho natsional'noho universytetu imeni Tarasa Shevchenka. - Pedahohika. - 2018. - № 2(8). - P. 17-20.

3. Zhylenko M. V. Orhanizatsiya osobystoyi diyal'nosti kerivnyka, yak umova efektyvnoho upravlinnya zakladom osvity / M. V. Zhylenko // Visnyk
Kyyivs'koho natsional'noho universytetu imeni Tarasa Shevchenka. Pedahohika. - 2019. - № 2 (10). - P. 60-65.

4. Zakon Ukrayiny "Pro vyshchu osvitu" vid 01.07.2014 roku № 1556-18 // Vidomosti Verkhovnoyi Rady Ukrayiny vid 19.09.2014 - 2014 r., / № 37-38 /, stor. 2716, stattya 2004 [iz zminamy ta dopovnennyamy] [Elektronnyy resurs] II Verkhovna Rada Ukrayiny: [sayt]. - Rezhym dostupu: http://zakon3.rada.gov.ua/laws/show/1556-18/print

5. Mitsich P. How to conduct business conversations / P. Mitsich; abbr. per. with Serbian Horv. ; 2nd ed. - M. : "Economics", 1987.

6. Skibits'ka L. I. Orhanizatsiya pratsi menedzhera : navch. posibnyk. - K. : Tsentr uchbovoyi literatury, 2010. - P. 137.

7. Standart vyshchoyi osvity Ukrayiny. Riven' vyshchoyi osvity druhyy (mahisters'kyy) haluzi znan' 07 "Upravlinnya ta administruvannya", spetsial'nosti 073 "Menedzhment" [Elektronnyy resurs] // Ministerstvo osvity i nauky Ukrayiny: [sayt]. - Rezhym dostupu: (http://www.management.com.ua/ books/view-books.php?id=22)

Надійшла до редколегії 27.01.20

N. Zhylenko,Ph.D, Associate Professor

Taras Shevchenko National University of Kyiv, Kyiv, Ukraine

\title{
CONDITIONS FOR EFFECTIVE DELEGATION OF POWERS BY THE MANAGER OF A HIGHER EDUCATION INSTITUTION
}

The article deals with the level of readiness of the manager of the Free Economic Zone to delegate his powers and summarizes the experience of such activities. During the study of the activities of vice-rectors, heads of departments, deans of faculties, directors of institutes, educational and research centers of higher education, it was found that the head (manager), as a subject of management, must be able to analyze the situation, predict strategy, plan tactics to achieve defined goals and organize operational management for their implementation. But most of the respondents approach the solution of this problem at the level of everyday consciousness, do not always understand that management is first of all the ability to organize teamwork. The effectiveness of managerial work in a higher education institution largely depends on the personal characteristics of the head, but a mandatory component of its productivity are competencies that can not be formed without special knowledge. The procedure for election and appointment does not provide for the availability of such knowledge. The manager of an educational institution can hardly influence the level of predictability of tasks that have an external nature, while the professional organization and streamlining of the structure of internal activities provides significant advantages. One of the ways to optimize the structure of the internal activities of the manager and increase its efficiency is the willingness and ability to delegate their powers. This, as part of a well-planned work, gives the manager the greatest reserve of time. Analysis of the practice of successful managers and scientific literature on this issue, allowed to formulate and test recommendations to managers for successful delegation of authority, which involves the use of certain principles of delegation, a clear understanding of the types and scope of work, work that can be delegated; understanding the procedure and procedure for setting goals and setting goals; taking into account the professional capabilities of staff. It is proved that an important condition for effective delegation is the master's mastery of the logic of formulation and the procedure of setting reasonable goals, which should provide a busy rhythm for each employee, taking into account the goals and personal and professional capabilities.

Keywords: paradigm, branch of knowledge, speciality, educational program, subject area.

\section{ОСНОВНІ НАПРЯМИ ПСИХОЛОГІЧНОГО КОНСУЛЬТУВАННЯ В РОЗВ'ЯЗАННІ ВНУТРІШНЬООСОБИСТІСНИХ КОНФЛІКТІВ СТУДЕНТІВ І ВИКЛАДАЧІВ: ЗАРУБІЖНИЙ I ВІТЧИЗНЯНИЙ ДОСВІД}

Здійснено аналіз актуальних ідей із проблеми розв'язання внутрішніх конфоліктів студентів $і$ викладачів, що $є$ основою для педагогічних конфліктів у вищій школі. Особливий акцент поставлено на ресурсних можливостях напрямів психологічного консультування в розв'язанні внутрішньоособистісних конфліктів. Різні психологічні напрями, школи подають специфічні визначення, структуру, динаміку психологічного консультування. Увагу закцентовано на підвищенні рівня ефективності психологічного консультування та на самовідчутті кліснта. Процес консультування може здійснюватися в діапазоні від однісї до деякого кількості психологічних сесій. Наслідки консультування можна розглядати з погляду змін, що відбуваються в особистості клієнта, і ступеня його задоволеності результатами консультування. У цьому процесі виняткову увагу приділено еклектичній консультативній бесіді. Детально розглянуто її зміст, характеристику, принципи, специфіку, етапи, стадії. Узагальнено функції, мету, процедуру консультативної бесіди у вищій школі, що тлумачиться як динамічний процес, під час якого викладач-консультант допомагає студентові використати свої внутрішні ресурси для розвитку й актуалізації потенціалу осмисленого життя. Консультативна бесіда - суб'єкт суб'єктна взаємодія, яка будується та підтримується за партнерського стилю відносин; метою якого є взаємне збагачення досвідом, саморозвиток обох сторін і розв'язання проблем студента. Внутрішні конфлікти, які розв'язані конструктивно, позитивно впливають на особистість, забезпечують ї̈ подальше професійне зростання, вселяють віру в себе та в людей. Знання й базові компетентності з динаміки, специффіки внутрішніх конфліктів здатні заощадити час, зберегти продуктивність, здоров'я, підвищити креативність, професійну, інтелектуальну й особистісну компетентність студентів, викладачів і керівників закладів вищої освіти освіти. Деструктивно розв'язані коноллікти мають у собі протилежне й можуть призвести до неврозів, депресій, афективних станів, психічних захворювань, які, у свою череу, є ґрунтом для інших соматичних хвороб. Тому так важливо розв'язувати конфллікти 3 позитивним наслідком, який спричиняє, зокрема, доцільно вжитий інструментарій психологічного консультування.

Ключові слова: психологічне консультування, розв'язання внутрішньоособистісних конфліктів, педагогічні конфрлікти, студенти, викладачі.

Постановка проблеми. У наш складний час активної трансорормації, модернізації й інтеграції вищої освіти України та зарубіжжя постійно відбуваються пошуки нових міждисциплінарних парадигм, ефективних моделей насичених інноваційними технологіями професійного розвитку особистості студента. Новітні суспільні запити та 
виклики призводять до стресу, конкуренції, конфліктності учасників освітнього процесу, фоормують соціальне замовлення на зміст фрахової підготовки студентів і на постійний саморозвиток викладачів, які, відповідно до вимог часу, повинні не лише орієнтуватися в новітніх освітніх підходах, а й набувати відповідних навичок i вмінь, що базуються на суміжному мультикультуральному надбанні сучасної науки.

Таким її прикладом є відносно нова царина гуманітарного знання - педагогічна конфрліктологія, що виникла на перетині кількох наук і вже викладається як навчальна дисципліна у вищій школі для ОС "Магістр" спеціальності 011 - "Освітні, педагогічні науки" освітньої програми "Педагогіка вищої школи". Вивчення студентами педагогічної конфліктології та оволодіння ними відповідними компетенціями передбачає 50 \% практичних занять. Це дозволяє студентам пройти необхідне (зважаючи на відповідний закордонний досвід фрахової підготовки) особистісне консультування з актуальних проблем, відчути себе клієнтом та отримати практичний цінний досвід консультативної взаємодії із викладачем, який повинен мати психологічну підготовку.

Ґенеза педагогічної конфліктології як навчальної дисципліни обумовлена обмеженістю спеціалізації в підготовці фахівців, що потребує комплексного еклектичного поєднання, обґрунтування та впровадження доробку 3 історії, фрілософрії, педагогіки і психології. Цьому сприяє особистісно орієнтований підхід у психологічному консультуванні. Він став основою для напрацювань учених і практиків у розв'язанні внутрішньоособистісних конфліктів у зарубіжній і вітчизняній літературі. Знання й базові компетентності з динаміки, специфіки внутрішніх конфліктів здатні заощадити час, зберегти продуктивність, здоров'я, підвищити креативність, професійну, інтелектуальну й особистісну компетентність студентів, викладачів і керівників закладів вищої освіти освіти.

Внутрішньоособистісний конфлікт - це стан незадоволеності та психологічний механізм індивіда, у якому відбуваються зіткнення суперечливих інтересів, прагнень, потреб, функціональних вимог, які витікають із різних статусів; це специфічне протиріччя між новою інформацією й цінностями індивіду [4, с. 66]. Внутрішні конфрлікти підпорядковуються закону збереження енергії: енергія не зникає і не виникає з нічого, а перетворюється 3 одного виду в інший. Увесь життєвий шлях індивід формується й розвивається у процесі безпосереднього становлення і розв'язання протиріч, що є винятково важливим для студентського віку [5].

Внутрішні конфлікти, які розв'язані конструктивно, позитивно впливають на особистість, забезпечують ії̈ подальше зростання, вселяють віру в себе та в людей. Деструктивно розв'язані конфлікти несуть у собі протилежне. Їхній негативний вплив полягає у "зламі" особистості, відчутті своєї нікчемності, свого безсилля що-небудь зробити. Деструктивні конфлікти можуть призвести до психічних захворювань, які, у свою чергу, є ґрунтом для інших соматичних хвороб. Тому так важливо розв'язувати конфолікти з позитивним наслідком, який спричиняє, зокрема, доцільно вжитий інструментарій психологічного консультування. У цьому процесі студент занурюється в роль клієнта, а викладач - консультанта для того, щоб згодом (для поліпшення міжособистісного взаєморозуміння та взаємодії) помінятися ролями.

Аналіз останніх досліджень і публікацій. Популярними конфрліктологами кінця XX початку XXI ст. визнані зарубіжні науковці: А. Адрі, Дж. Бертон, К. Бікмор [20], Р. Буллоу, П. Ван де Берге, Г. Граффр [23], Т. Гутірез-
Шміх [26], Д. Дана, Н. Джараміло [22], Л. Крісберг, К. Кумашіро [25], К. Лоренц, Д. Моріс, А. Обершелл, У. Самнер, В. Сатір, Д. Скотт, Ч. Тіллі, Е. Уілсон, Р. Фішер [21], Р. Фокс, В. Юрі й ін.

Серед праць американських конфліктологів заслуговують уваги роботи А. Обершелла "Соціальний конфлікт та громадський рух" (1973), Ч. Тіллі "Від мобілізації до революції" (1978), Л. Крісберга "Соціальні конфлікти" (1973, 1982), Р. Фішера та В. Юрі "Шлях до злагоди" (1983), Д. Скотт "Конфлікти та шляхи їх подолання" (1991). Доробок цих авторів створив засади розвитку педагогічної конфрліктології за кордоном.

Сучасні американські конфліктологи значну увагу приділяють педагогічним і внутрішнім конфрліктам. Підтвердженням тому - роботи К. Бікмор "Практичний конфлікт: громадянське виховання у вузах соціальних наук" (1991), Г. Граффра "Конфрліктна педагогіка і студентський досвід" (1995), Р. Фішера "Оприлюднення навчального плану з врегулювання конфліктів та мирної освіти: майбутні напрями критичної конфліктологічної освіти та педагогіки конфлікту" (2000), Н. Джараміло "Педагогіка невиконання" (2010), Т. Гутірез-Шміх "Громадська педагогіка і конфліктна педагогіка: можливості для педагогічної освіти" (2016) та ін.

Узагальнюючи основний зміст цих праць, доходимо висновку, що у США та Канаді між науковцями велися дискусії стосовно первинного вживання терміну "педагогічна конфліктологія" - "Conflict Management Education" (управління конфліктами освіти), яке далі було замінено на "Critical Pedagogy" (критична педагогіка), "Conflictual Pedagogy" (конфліктологічна педагогіка), а згодом "Pedagogy of Conflict" (педагогіка конфлікту), "Conflict Pedagogy" (конфлліктна педагогіка). Сьогодні саме останній термін набув поширення серед наукової спільноти. Conflict Pedagogy - це галузь наукового знання, вчення, що містить теоретичні основи, альтернативні способи як найкраще навчати та вчитися долати "тут і тепер" гострі конфлікти та насильство [21, с. 3].

Аналіз наукової літератури з проблеми конфліктів дозволяє стверджувати, що вітчизняні вчені Н. Ануфрієва, $€$. Дурманенко, І. Козич в основному досліджували специфіку соціально-педагогічних конфліктів у закладах освіти. Г. Антонов [1], І. Ващенко [4], Т. Дзюба, М. Кляп [4], розглядали деякі аспекти динаміки конфліктів у вищій школі. Т. Дрожжина, М. Мосьпан особливу увагу зосереджували на профрілактиці конфліктних ситуацій у педагогічній діяльності.

Проблематика педагогічних конфліктів досліджувалася багатьма фахівцями та була представлена в численних публікаціях В. Афонькової, С. Баникіної, В. Басова, Б. Жизневського, В. Журавльова, В. Казанської, Е. Кіршбаума, Я. Коломийського, А. Ліханова, М. Рибакової, Л. Симонової, О. Соколової, С. Сулейманова, Т. Чистякова, Н. Шеляховської й ін.

Значну увагу проблематиці внутрішньоособистісних конфрліктів приділяли науковці І. Булах, Л. Бурлачук [3], Ф. Василюк, О. Донченко [7], Е. Зеєр, А. Кунцевська, С. Кузікова, Г. Ложкін, С. Максименко, Л. Орбан, М. Пірен, Н. Пов'якель, Е. Симанюк, В. Столін, Т. Титаренко [7], В. Шанда, Н. Чепелєва, Є. Юрківський та ін. Переважна більшість із них у розв'язанні внутрішніх конфліктів особистості використовують різні напрями психологічного консультування.

Консультування, як динамічний процес, є досить поширеним і широко досліджуваним у сферах психології, медицини, управління персоналом тощо. У закладах вищої освіти надаються різні види консультування: психологічне, 
соціально-педагогічне, методичне й ін. Безпосередньо психологічне консультування стало прерогативою діяльності О. Бондаренка [2], І. Грабської, І. Дубровіної, О. Зайченка, А. Кочюнаса [11], В. Мєновщикова [13], Н. Калини [10], М. Певзнер, Н. Тутушкіної [16], В. Хохлова й ін.

Психологічне консультування - це сукупність процедур, спрямованих на допомогу індивіду в розв'язанні його проблем і прийнятті рішень щодо кар'єри, шлюбу, сім'ї, удосконалення особистості й міжособистісних стосунків. Ціль консультування - допомогти клієнтам зрозуміти те, що відбувається у їхньому життєвому просторі й осмислено досягти поставленої цілі на основі усвідомленого вибору при розв'язуванні проблем емоційного та міжособистісного характеру [11, с. 46-47].

Існує багато подібних визначень, і всі вони включають декілька основних положень, що психологічне консультування: + допомагає людині діяти на власний розсуд; + сприяє новій поведінці; + позитивно впливає на розвиток особистості; + акцентує увагу на відповідальності клієнта, тобто визнається, що незалежний, відповідальний індивід (студент) спроможний у відповідних обставинах приймати самостійні рішення, а консультант (викладач) створює умови, що заохочують вольову поведінку клієнта.

Мета статті полягала в тому, щоб проаналізувати й охарактеризувати основні підходи психологічного консультування в розв'язанні внутрішньоособистісних конфрліктів студентів і викладачів. Для досягнення мети реалізовувалися такі завдання:

- проаналізовано зміст, історію, специфіку основних підходів психологічного консультування;

- охарактеризовано сутність розв'язання внутрішніх конфрліктів студентів і викладачів;
- обґрунтовано консультативну бесіду в розв'язанні таких конфліктів.

Викладення основного матеріалу. Початок історії розвитку психологічного консультування варто шукати в глибині віків. Однак лише з кінця XVII ст. зроблено спроби науково пояснити психічні методи лікування. Починаючи 3 "магнетичного фрлюїду" віденського лікаря А. Месмера: у XIX ст. Дж. Бред (гіпноз), у XX ст. 3. Фрейд (психоаналіз), Е. Берн (транзакційний аналіз), Ф. Перлз (гештальт-терапія), К. Роджерс (клієнт-центрована терапія), М. Еріксон (нетрадиційний гіпноз і терапія), В. Сатір (сімейна терапія) і багато інших. I якщо спочатку психотерапія була прерогативою лікарів, то на початку XX ст. до них поступово долучається практичні психологи без відповідної медичної освіти, соціальні педагоги, працівники соціальних служб, а в 1950-х рр. у США виокремлюється консультативна психологія. Перефразуючи Г. Ебінгауза, можна сказати, що психологічне консультування має тривале минуле, але консультативна психологія лише коротку історію [6].

У кінці XX ст. психологічний вплив у Росії, як і в Україні, частіше називали психотерапією, якщо ним займався лікар, і психокорекцією, якщо його застосовував психолог. Це обмеження було штучним. До того ж термін "психотерапія" $є$ міжнародним на противагу "психокорекції". Консультування від психотерапії відрізняє відмова від концепції хвороби. У цьому контексті існують принаймні чотири близьких за змістом поняття: психотерапія, психокорекція, нелікарняна психотерапія, психологічне консультування на яких закцентував специфічну увагу російський дослідник В. Мєновщиков у праці "Введення у психологічне консультування" ("Введение в психологическое консультирование").

Порівняння понять психотерапія, психокорекція, нелікарняна психотерапія,

Таблиця 1 психологічне консультування за В. Мєновщиковим [13, с. 7]

\begin{tabular}{|c|c|c|c|}
\hline Напрям & Суб'єкт & Об'єкт & Ціль \\
\hline $\begin{array}{l}\text { Психотерапія } \\
\text { І. Клінічно-орієнтована } \\
\text { II. Особистісно-орієнтована }\end{array}$ & $\begin{array}{l}\text { Лікар (психіатр, } \\
\text { психотерапевт) } \\
\text { Лікар, психолог }\end{array}$ & $\begin{array}{l}\text { Хворий, пацієнт } \\
\text { Хворий, клієнт }\end{array}$ & $\begin{array}{l}\text { Ліквідація симптомів хвороби } \\
\text { Особистісні та міжособистісні зміни }\end{array}$ \\
\hline Психокорекція & Лікар, психолог & Хворий, клієнт & $\begin{array}{l}\text { Виправлення різних психічних розладів, нормалізація } \\
\text { психічної діяльності }\end{array}$ \\
\hline Нелікарняна психотерапія & Психолог & Клієнт & \begin{tabular}{|l|} 
Оптимізація взаємостосунків \\
(наприклад, у проблемних сім'ях)
\end{tabular} \\
\hline Консультування & $\begin{array}{l}\text { Консультуючий } \\
\text { психолог, } \\
\text { соціальний працівник }\end{array}$ & Клієнт, сім'я, група & $\begin{array}{l}\text { Адаптація до життя за рахунок активізації особистісних } \\
\text { ресурсів (вихід із важкої життєвої ситуації) }\end{array}$ \\
\hline
\end{tabular}

Далі узагальнимо напрями саме психологічного консультування в розв'язанні внутрішніх конфліктів особистості. У навчальному посібнику "Психологічна допомога особистості" О. Бондаренко [2, с. 53-55] авторитетно й переконливо стверджує, що один із найвагоміших напрямів - психодинамічний, який базується на класичному психоаналізі 3. Фрейда. Науковець виділяє такі цілі психологічної допомоги: 1) усвідомлення неусвідомлюваного (мотивів, захистів, фріксацій т. д.) і прийняття адекватної реалістичної інтерпретації; 2) посилення Ego ("Я") для побудування реалістичнішої поведінки.

Роль психолога-консультанта в цьому процесі жорстко фріксована. Основні вимоги до нього: невтручання, нейтралітет та особиста замкненість; уміння витримувати "перенесення" та працювати з "контр-перенесенням"; спостережливість і здатність до адекватних інтерпретацій; усвідомлення власних проблем і їхній можливий вплив на клієнта. Обов'язковою умовою підготовки психоаналітика $€$ проходження курсу власного психоаналізу.
Вимоги й очікування від клієнта полягають у сприйняття самої концепції психоаналізу; повна відкритість і готовність до тривалого (від кількох місяців до кількох років) періоду спільної роботи; клієнт бере на себе відповідальність утримуватися від різких перемін в особистому житті протягом курсу психоаналізу. У класичному психоаналізі використовуються такі методики: а) метод вільних асоціацій; б) тлумачення сновидінь; в) інтерпретація; г) аналіз опору; д) аналіз перенесення.

3. Фрейд виявив вирішальну роль мови для психоаналітичного лікування. Стимулюючи вербалізацію причин конфлікту, можна змінити та впорядкувати уявлення людини про себе, а головне, підключити зусилля самого хворого до власного видужання. Для цього лікар досліджує особливості та взаємовідносин між "Воно" ("Id"), "Я" ("Ego") і "Над-Я" ("Super-ego") [2, с. 54-55].

Аналіз літератури [17] дозволив виділити такі стадії психоаналізу. Перша стадія - пошук хворобливого осередку. Застосовуються метод асоціацій, спостереження 
за поведінкою людини, вивчаються описки, обмовки, гумор людини. За кількістю випадків, розказаних на деяку тему, можна визначити, у якій площині міститься хворобливий осередок. Друга стадія - скресання осередку порушення, вербалізація. Особистість виговорюється, розповідає психологу про свої переживання і їхні джерела. Третя стадія - переоцінка значимості подій, прихованих у хворобливому осередку, так зване "переклеювання ярликів". Наприклад, із "коханого" - у "друга" і т. д. На цій стадії дуже важлива допомога у зміні системи установок. Четверта стадія - емоційне позитивне, спокійне фарбування нової системи установок. Не варто різко переходити від любові до ненависті. П'ята стадія забування, ліквідація осередку порушення. Найчастіше ця стадія проходить природним шляхом як продовження роботи з психологом. Звичайно, це спрощена схема методу психоаналізу. Поряд із психоаналізом бажаний постійний детальний глибинний самоаналіз, про який пише К. Хорні у праці "Наші внутрішні конфлікти" [18, с. 9].

Аналітична психологія К. Юнга має за мету навчанню осягненню власного внутрішнього світу й самопізнанню за допомогою переживання всієї повноти свого буття, що в перспективі приводить до індивідуації. К. Юнг прагнув міркувати не про хворобу клієнта, а про "загальний невроз віку". К. Юнг сформулював не клінічне, а екзистенційне розуміння проблематики клієнтів, пов'язане із втратою сенсу буття.

Роль психолога-консультанта жорстко не фіксується. Він будує свої терапевтичні стосунки з клієнтом частково аналогічно психоаналітичній традиції, частково ні. Схожість полягає у використанні перенесення та контр-перенесення. Відмінність - у забезпеченні прийняття клієнта та у специфіці роботи з його внутрішнім світом. Важливим моментом є допомога клієнтові в розподіленні усвідомлюваних і неусвідомлюваних інстанцій та встановленні комунікації між ними.

Саме так, як 3. Фрейд відмовлявся працювати із шизоїдами, юнгіанський аналітик виключає зі своїх клієнтів алкоголіків, наркоманів та осіб з суїцидальними або агресивними тенденціями, що стали предметом особливої уваги й дослідження спочатку Е. Дюркгейма [8], а згодом - Д. Єнікєєвої [9] і багатьох інших науковців. Єдиною умовою стосовно інших клієнтів $€$ наявність визначеної мотивації. Психотехніка аналогічна психоаналізові, але набагато більше уваги приділяється тлумаченню сновидінь, де контекст інтерпретацій далеко виходить за межі сексуальних конотацій, а символіка трактується не редукціоністсько-біологічним, а культурологічним чином [2, с. 70-72].

Транзактний аналіз Е. Берна висуває такі цілі психологічної допомоги: допомогти клієнтові усвідомити свої "Его-стани" ("Батько", "Дитина", "Дорослий"), ігри, життєвий сценарій, і - за необхідністю -прийняти нове рішення, стосовно поведінки й побудови життя, звільнити людину від виконання нав'язаних програм поведінки й допомогти їй стати незалежною, спонтанною.

Позиція психолога передбачає партнерство, прийняття клієнта, сполучення позицій учителя й експерта, забезпечення необхідного інсайту. У літературі зазначається, що психолог зобов'язаний апелювати до Егостану "Дорослий" у клієнта, а не потурати невротичним стереотипам. Позиція клієнта передбачає укладання обопільної угоди про умови роботи й характер стосунків. Клієнтові відводиться роль анонімного учасника, який ставить власні цілі з указанням критеріїв оцінки їх досягнення. Така форма спільної роботи передбачає взаємну відповідальність обох сторін [2, с. 87-89].

Особливого значення набуває поведінковий напрям у консультуванні. Головним у ньому $є$ забезпечення нових умов для навчання, тобто вироблення нового обумовлення й на цій основі допомога в оволодінні новою поведінкою; формування нових соціальних вмінь; оволодіння психологічними цілями саморегуляції; подолання шкідливих звичок і зняття стресу; позбавлення емоційних травм тощо.

Роль психолога-консультанта - це роль учителя, наставника або лікаря. Відповідно психолог має бути готовий взяти на себе вантаж зразка для наслідування, яким він виступає в думках клієнта, а також усвідомлювати специфіку захисного механізму ідентифікації, що відіграє для клієнта важливу роль. Вимоги до клієнта: активність, свідомість у постановці цілей, бажання співпрацювати із психологом та імпровізація з новими формами поведінки [2, с. 96-98].

Найважливішим моментом у психологічній позиції клієнта є готовність до застосування нових форм поведінки. Техніка психологічної роботи в біхевіоральному напрямку будується на детерміністичному посиланні, що певна поведінка $€$ наслідком певного впливу. Це означає, що дезадаптивна (невротична) поведінка є результатом невірного навчання. Тому основою психотерапії $€$ сукупність прийомів формування нової поведінки (перенавчання), основана на експериментальних дослідженнях і теоретичних допущеннях біхевіоризму.

Цікавим і специфічним у своєму обґрунтуванні є когнітивний напрям, який має ряд варіантів. О. Бондаренко детально аналізує деякі з них [2, с. 95-97]. Зокрема, раціонально-емотивна терапія (РЕT) А. Еліса, який запропонував чотирикомпонентну структуру особистості A-B-C-D-теорія. Аналіз поведінки клієнта або самоаналіз за схемою: "подія-сприйняття-реакція-обдумування-висновок" володіє високою продуктивністю та ефектом навчання. У літературі відзначаються такі психологічні передумови РЕТ: 1) визнання особистої відповідальності за свої проблеми; 2) прийняття ідеї, що є можливість рішуче вплинути на ці проблеми; 3) визнання, що емоційні проблеми беруть початок з ірраціональних уявлень; 4) віднаходження (усвідомлення) цих уявлень; 5) визнання корисності серйозного обговорення цих уявлень; 6) згода докладати зусилля до конфронтації із своїми алогічними судженнями; 7) згода на використання РЕT. Допомога полягає у перегляді системи переконань, норм та уявлень, увільнення від ідеї самозвинувачення.

Позиція психолога безумовно директивна. Він роз'яснює, переконує, він - авторитет, який відкидає помилкові судження, вказуючи на їхню недоцільність, довільність, апелює до науки, до здатності мислити. Клієнту відведено роль учня, його успіх трактується залежно від мотивації й ідентифікації з роллю учня. Передбачається, що клієнт проходить три рівні інсайту: поверховий (усвідомлення проблеми), заглиблений (розпізнавання власних інтерпретацій) і глибинний (на рівні мотивації до змінення).

Іншим відгалуженням когнітивного напряму є реальнісна терапія У. Гласерра [2, с. 110-111]. Концепція призначена насамперед для роботи з "важкими" підлітками. Також застосована в роботі з ув'язненими. У реальнісному консультуванні приділяється особлива увага стосункам із клієнтом (подружитися, прийняти), заохочуванню клієнта до оцінювання його поведінки. Допомога в пошуку альтернативних способів дій і виробленні плану. План має бути простим і зрозумілим, конкретним (що, коли, де і як). Наявна відмова у прийнятті вибачень, жорсткість, але без застосування покарань. I, головне, у жодному разі консультант не повинен відмовлятися від клієнта, від роботи з ним.

Відносно новим напрямом у консультуванні $є$ гуманістичний, що також має варіації. Зокрема, екзистенційне 
консультування. Цілі психологічної допомоги: допомогти клієнтові віднайти смисл свого власного життя; усвідомити особистісну свободу й відповідальність; розкрити свої потенції як особи в повноцінному спілкуванні. Безумовне визнання особистості клієнта та його долі найважливішим, унікальним і безумовно заслуговуючим поваги "життєвим світом", існування якого є самоцінність.

Позиція психолога-консультанта передбачає розуміння клієнта в термінах його власного життєвого світу, його власного бачення себе й дійсності. Основну увагу психолог-консультант приділяє поточному моменту життя клієнта та його нинішнім переживанням. Психолог повинен уміти поєднувати розуміння клієнта і здатність до конфронтації з тим, що називається "обмеженим існуванням" у клієнті. У клієнті заохочується відкритість, спонтанна активність і зосередженість на основних проблемах життя (народження, любов, тривога, доля, провина, смерть, відповідальність), тобто на екзистенційних проблемах, які не мають розв'язання раціонального, але конфронтація з якими дозволяє розв'язувати поточні психологічні проблеми [2, с. 122-123].

Представники екзистенційної психології відкидають значущість будь-яких психотехнік у консультативній роботі (Л. Бінсвангер, В. Франкл, Р. Мей [12], І. Ялом та ін). В екзистенційному консультуванні йдеться про підходи до особистісної проблематики клієнта. Їхня суть така: 1) акцент на розвитку самосвідомості; 2) культивування свободи й відповідальності; 3) допомога у відкритті або створенні смислу; 4) унікальність та ідентичність; 5) робота із тривогою. Взаємостосунки клієнта із психологом $\epsilon$ самоцінністю. Повага, довіра, саморозкриття, відмова від маніпулювання, ненав'язування своєї поведінки та неперетягування на психолога відповідальності - така основа цих стосунків.

Клієнт-центроване консультування К. Роджерса [14] висуває за мету допомогти людині стати "всеціло діючою особою"; сприяти особистісному зростанню, завдяки якому людина сама розв'язує свої проблеми; створювати відповідний "психологічний клімат". Увага концентрується не на проблемах людини, а на ії "Я".

Роль психолога-консультанта потребує відмовитися від спроб грати якусь роль, спробувати бути самим собою; створити відповідний психологічний клімат, коли клієнт сам би відмовився від захисних механізмів. При цьому найважче - бути "справжнім" у спілкуванні з клієнтом (повага, турбота, сприйняття й розуміння). Очікується, що клієнт почуватиме себе безпомічним, поводитиметься неконгруентно, очікуватиме допомоги й буде досить замкненим. Із встановлення терапевтичних стосунків відбувається світосприйняття та фрормування іншого ставлення до себе.

Окрім трьох основних компонентів роджеріанської психотехніки (конгруентності, емпатійного слухання й турботи) аналіз літератури дозволив виділити сім етапів консультативного процесу: 1) заблокованість внутрішньої комунікації (відсутнє Я-повідомлення, заперечується наявність проблем, відсутнє бажання до змін); 2) самовираження (клієнт починає в атмосфері прийняття відкривати свої почуття, проблеми); 3) розвиток процесу саморозкриття; 4) сприйняття себе клієнтом в усій складності, обмеженості й незавершеності; 5) процес ставлення до свого френоменологічного світу як до власного, долається відчуженість від свого "Я", зростає потреба бути собою; 6) інтегрування особистісного досвіду в одне ціле (розвивається конгруентність, відповідальність, встановлюється вільна внутрішня комунікація, поведінка й самовідчуття "Я" стають органічними); 7) стадія особистісних змін, стадія відкритості себе та світу, психолог уже стає непотрібним, адже досягнено головної мети - стану конгруентності із собою та світом, реалістичного балансу між "Я-реальним" і "Я-ідеальним" [14].

Цінним, із погляду на результативність розв'язуваних проблем, є гештальт-консультування. За Ф. Перлсом, який полюбляв порівнювати структуру особистості з цибулиною, варто скинути п'ять шарів невротичності, аби досягти психологічної зрілості особистості: 1) шар фальшивої рольової поведінки; 2) шар фоббій (клієнт прагне уникати зіткнення зі своїми хворобливими переживаннями); 3) шар "безвиході й розпачу" (моменти, пов'язані з переживанням своєї власної безпомічності); 4) шар доступу до свого справжнього "Я" (людина у сльозах розпачу переживає свою рішучість прийняти ситуацію та справитися з нею); 5) шар емоційного вибуху (клієнт скидає із себе фальшиве та починає жити й діяти від свого справжнього "Я").

Цілями психологічної допомоги є забезпечення повноцінної роботи актуального самоусвідомлювання; зміщення локусу контролю всередину, заохочення незалежності та самодостатньості; віднаходження психологічних блоків, що перешкоджають зростанню та зживанню ними. У гештальт-консультуванні психолог розглядається як "каталізатор", "помічник" і співтворець, інтегрований у єдине ціле, у "гештальт" особи клієнта. Психолог прагне уникати безпосереднього втручання до особистих почуттів клієнта, швидше він намагається полегшити вираження цих почуттів [2, с. 134-135].

Позиція клієнта - активна, яка містить у собі право на власні інтерпретації, позиції, i, головне, - на усвідомлення "патернів", схем своєї поведінки та життя. Клієнт повинен перемкнутися з раціоналізування на переживання. Вербалізація почуттів не настільки важлива, як бажання клієнта та його готовність прийняти сам процес актуального переживання, у якому він насправді переживатиме почуття, і говорити від їхньго імені, а не просто повідомляти про них. Психотехнікам, які в цьому напрямі йменуються також "ігри" й "експерименти", у гештальттерапії надають великого значення. Більш того, гештальт-терапія стала відомою завдяки саме цим "іграм", "трюкам". Техніки: "навпаки", "експерементальне перебільшення", "психодрама", "і я несу за це відповідальність", "дисоційований діалог" тощо.

Узагальнюючи зарубіжний досвід здійснення психологічного консультування робимо висновок, що різні психологічні напрями, школи подають специфічні визначення, структуру, динаміку психологічного консультування. Проте, в основному увага акцентується на підвищенні рівня ефрективності психологічного консультування та на самовідчутті клієнта. Процес консультування може здійснюватися в діапазоні від однієї (45-60хвилинної) до певної кількості психологічних сесій. Наслідки консультування можна розглядати з погляду змін, що відбуваються в особистості клієнта, і ступеня його задоволеності результатами консультування.

Ситуація із психологічним консультуванням у нашій країні подібна до тих, що переживали європейські країни більше 40-50-ти років тому, коли консультування стало необхідним компонентом у різноманітних сферах суспільного устрою. М. Херберт, відомий сучасний британський психолог, описує цю ситуацію так: "...консультанти всюди...ви можете зустріти їх у школах, промислових підприємствах, лікарнях, соціальних службах... існують консультанти з питань шлюбу, розводу, розвитки кар'єри, гострої втрати, консультування батьків, пенсіонерів і т. д." [16, с. 56].

Відношення вітчизняних психологів до консультування натепер полярне: одні вважають, що психологічне 
консультування не має власного предмета і є лише прикладною галуззю інших теоретичних розробок у психології; інші - ігнорують теоретичні основи консультування й розглядають його як набір практичних методів і прийомів до роботі. Консультування є однієї з форм допомоги людям у розв'язанні їхніхє проблем і, звичайно, не може відповісти на всі питання. Психологічне консультування в межах одного підходу буде різноманітним залежно від галузі застосування.

Як влучно зазначає О. Бондаренко у своїй праці "Психологічна допомога особистості" в галузі психологічної допомоги цілком визначені труднощі, пов'язані як із специфрікою професії, так і з невизначеністю статусу психолога-консультанта у пострадянському суспільстві. Зіставимо, наприклад, ситуацію звернення клієнта до представника будь-якої іншої професії системи "людина-людина". У таких випадках користувач: а) знає, чого він хоче; б) ознайомлений так чи інакше про норми взаємостосунків із представником цієї професії; в) досить добре розуміє міру відповідальності й обмежень свою та професіонала, до якого звертається. Скажімо, пацієнт розуміє можливості того, що результат лікування не залежить виключно від кваліфікації лікаря та його рекомендацій навіть за наявності найнеобхідніших медикаментів. У вітчизняному психологічному консультуванні майже всі напрями запозичені із зарубіжного.

Психологічне консультування $€$ відповіддю на потреби індивідів (студентів), що не мають клінічних порушень, але шукають психологічної допомоги. Спектр проблем широкий: труднощі діяльності (конфлікти з одногрупниками, викладачами), невпорядкованість особистого життя, негаразди в сім'ї, болісні вагання у прийнятті рішень, труднощі в налагоджуванні й підтримці міжособистісних стосунків і т. п.

Одним із найважливіших способів здійснення психологічного консультування $€$ консультативна бесіда. Консультативна бесіда - один із найголовніших методів надання психологічної допомоги. Як зазначає О. Бондаренко [2, с. 33], консультативна бесіда наближена до соціологічної техніки опитування, що називається "глибинне інтерв'ю". Консультативна бесіда - суб'єкт-суб'єктна взаємодія, яка будується та підтримується на партнерському стилі відносин; метою якого є взаємне збагачення досвідом, саморозвиток обох сторін і розв'язання проблеми клієнта [16, с. 42]. Консультативна бесіда особистісно-орієнтоване спілкування, де здійснюється загальне орієнтування у власних особливостях і проблемах клієнта, надається психологічна допомога відповідно до потреб, проблематики й характеру консультативної роботи. Консультативна бесіда, залежно від етапу роботи, буває: початковою, процесуальною, завершальною та підтримуючою. Ї̈̈ структура така: початок стосунків, їхній розвиток, динаміка, припинення стосунків [2, с. 33].

Жодна з теоретичних орієнтацій або шкіл психологічного консультування не відбиває всі можливі ситуації взаємодії консультанта і клієнта. Тому розглянемо загальну модель структури консультативного процесу, названу еклектичною. Ії̈ запропонував Б. Гілланд і співробітники, а детально проаналізував Р. Кочюнас у праці "Основи психологічного консультування" [11, с. 18]. Ця системна модель, що охоплює шість тісно пов'язаних між собою стадій, відбиває універсальні риси консультативної бесіди будь-якої орієнтації між клієнтом (студентом) і консультантом (викладачем).

I. Дослідження проблем. Консультант-викладач установлює контакт із клієнтом-студентом і досягає довіри: уважно вислуховує, проявляє емпатію, не застосовує оцінок.

II. Двомірне визначення проблем. Консультант-викладач прагне точно охарактеризувати проблеми клієнта-студента, установлюючи як емоційні, так і когнітивні їхні аспекти. Уточнення проблем ведеться доки клієнт і консультант не досягнуть однакового їхнього розуміння. Точне визначення проблем дозволяє зрозуміти їхні причини, а іноді вказує й на засоби розв'язання.

III. Іентифрікація альтернатив. З'ясовуються та відкрито обговорюються можливі альтернативи розв'язання проблем. Користуючись відкритими питаннями, консультант-викладач спонукає клієнта-студента назвати всі можливі варіанти, допомагає висунути додаткові альтернативи.

IV. Планування. Здійснюється критична оцінка обраних альтернатив. Консультант-викладач допомагає клієнту-студенту розібратися, які альтернативи є реалістичними з погляду попереднього досвіду (перевірка альтернатив за допомогою рольових ігор, "репетицій" дій і ін.).

V. Діяльність. Відбувається послідовна реалізація плану розв'язання проблем. Консультант-викладач допомагає клієнту-студенту будувати діяльність з урахуванням обставин, часу, емоційних витрат, а також із розумінням можливості невдачі в досягненні цілей.

VI. Оцінка і зворотний зв'язок. Клієнт-студент разом із консультантом-викладачем оцінює рівень досягнення цілі й узагальнює досягнуті результати.

Ця модель допомагає лише краще зрозуміти, як відбувається конкретне консультування. Реальний процес - значно ширше й нерідко не підпорядковується цьому алгоритму. Виділення стадій умовне, оскільки у практичній роботі одні стадії поєднуються з іншими, і їхня взаємозалежність складніша. У процесі консультування важливі не стільки схеми, скільки фахова й особистісна компетентність консультанта. Адже, консультативна бесіда у вищій школі - це динамічний процес, під час якого викладач-консультант допомагає студенту використовувати свої внутрішні ресурси для розвитку й актуалізувати потенціал осмисленого життя.

Різні психологічні школи по-різному подають етапи, динаміку консультативної бесіди. Наведемо лише деякі з них. М. Тутушкіна виділяє три фрази динаміки консультативної бесіди: збір інформації, трансформацію системи, закріпляючі зміни [16, с. 198].

Незалежно від того, чи проводиться разова консультативна бесіда, або здійснюється пролонгована робота, консультування - діалектичний процес, що включає ряд стадій:

- укладання контракту між клієнтом і консультантом;

- пояснення запиту й аналіз проблемної ситуації, коли консультанту необхідно зорієнтуватися у проблемі клієнта, уважно слухаючи його, використовуючи перефразування для одержання достатньої інформації;

- переформулювання проблеми й постановка цілі, що супроводжується з'ясовуванням умов і ситуації виникнення проблеми, визначенням суті проблеми;

- пошук засобів розв'язання проблеми, коли необхідна згода клієнта на дослідження власних психологічних труднощів, пошук і прийняття на себе відповідальності за вибирані рішення.

О. Бондаренко виділяє таку динаміку процесу консультативної бесіди:

- етап входження до ситуації психологічної допомоги;

- етап діяння та прожиття ситуації психологічної допомоги;

- етап входження до нового досвіду; 
- останній етап - сходження до повсякденності збагаченим новим досвідом [2, с. 42-44].

Синтез вище наведених моделей дає змогу зупинитися на такій "п'ятикроковій" процедурі консультативної бесіди, яка сприяє більш ефективному розв'язанню внутрішніх конфрліктів студентів і викладачів.

"П'ятикрокова" поетапна процедура консультативної бесіди:

- встановлення контакту й орієнтування, мотивування особистості на роботу;

- збір інформації про проблему, ії̈ аналіз, розв'язання питання "У чому сутність, причини конфлікту?";

- усвідомлення бажаного результату, відповідь на запитання: "Чого прагнете домогтися?";

- вироблення альтернативних рішень, що можна позначити як: "Що ще можемо зробити і для чого?";

- узагальнення результатів взаємодії.

Висновки. Узагальнюючи вищеозначене, робимо висновок, що до XX ст. центром вивчення конфліктів була Західна Європа, де працювали 3. Фрейд, К. Юнг, Я. Морено й інші видатні вчені та діячі свого часу. Проте, коли конфоліктологія сформувалась як наука, саме США стали фрлагманом із ії вивчення й законодавцем правил і тенденцій у педагогічній конфрліктології.

Ефективність розв'язання внутрішньоособистісного конфлікту залежить від усвідомлення особистістю того, яка його структура, специфіка, динаміка. Знання, не перевірені практикою, не $є$ повноцінними. Шляхи розв'язання - це застосування не лише методу спроб і помилок, а й навчання на чужих невдачах. Теоретичними проблемами подолання внутрішньоособистісних конфрліктів займалися вітчизняні й зарубіжні науковців. Існують різні способи розв'язання внутрішніх конфліктів. Аналіз літератури та власний досвід допоміг виділити один із продуктивніших - психологічне консультування та його консультативну бесіду

Напрями психологічного консультування подають різні тлумачення консультативної бесіди. Проте увага акцентується на підвищенні рівня якості консультативної бесіди та на самовідчутті клієнта. Наслідки консультування можна розглядати з погляду змін, що відбуваються в особистості та ступеня ії̈ задоволеності результатами консультативних бесід. Важливо виділити можливі підсумки консультативної роботи: посилення уваги особистості до власних потреб, переживань і думок; розвиток здатності до самопізнання й усвідомлення нового досвіду; зміна ставлень до себе й довкілля; надбання здатності піклуватися про себе, самостійно розв'язувати свої проблеми, робити вибір, приймаючи рішення й несучи за них відповідальність.

\section{Список використаних джерел}

1. Антонов Г. В. Педагогічні засади запобігання і розв'язання конфліктів у навчально-виховному середовищі вищого навчального закладу : автореф. дис. на здобуття наук. ступеня канд. пед. наук: спец. 13.00 .04 теорія і методика професійної освіти / Г. В. Антонов. - Х., 2006.

2. Бондаренко О. Ф. Психологічна допомога особистості / О. Ф. Бондаренко - Х. : Фоліо, 1996

3. Бурлачук Л. Ф. Введение в проективную психологию / Л. Ф. Бурлачук. - К. : Ника-Центр, 1997.

4. Ващенко І. В. Конфліктологія та теорія переговорів : навч. посіб. / І. В. Ващенко, М. І. Кляп. - К. : Знання, 2013

5. Галузяк В. М. Педагогічна конфліктологія : навч. посіб. / В. М. Галузяк, І. Л. Холковська. - Вінниця : "Нілан", 2015.

6. Гірник А. М. Основи конфліктології : навч. посіб. / А. М. Гірник. - К. : Вид-во "Києво-Могилянська академія", 2010.

7. Донченко Е. А. Личность. Конфликт. Гармония / Е.А.Донченко, Т. М. Титаренко. - К. : Знание, 1989.

8. Дюркгейм Э. Самоубийство: Социологический этюд ; пер. с фр. / под ред. В. А. Базарова / Э. Дюркгейм. - М. : "Мысль", 1994

9. Еникеева Д. Д. Популярные основы психиатрии / Д. Д. Еникеева. Донецк : Сталкер, 1997.
10. Калина Н. Ф. Основы психотерапии / Н. Ф. Калина. - М. : Ваклер, 1996.

11. Кочюнас P. Основы психологического консультирования / Р. Кочюнас. - М. : Академический проект, 1999.

12. Мей Р. Искусство психологического консультирования / Р. Мей. М. : Клас, 1994.

13. Меновщиков В. Ю. Введение в психологическое консультирование / В. Ю. Меновщиков. - М. : Смысл, 1998

14. Роджерс К. Клиент-центрированная терапия / К. Роджерс. - М. : Ваклер, 1997

15. Семке В. Я. Умейте властвовать собой, или беседы о здоровой и больной личности / В. Я. Семке. - Новосибирск : Либроком, 1991.

16. Тутушкина М. К. Психологическая помощь и консультирование / М. К. Тутушкина. - СПб. : Дидактика Плюс, 1998.

17. Фрейд 3. Введение в психоанализ / З. Фрейд. - М. : Наука, 1991

18. Хорни К. Наши внутренние конфликты / К. Хорни. - СПб. : Лань, 1997.

19. Юрлов Ю.Н. Внутриличностные конфрликты курсантов высшего военного училища и их разрешение : дис ...канд. психол. наук / Ю. Н. Юрлов. - М., 1996.

20. Bickmore K. Practicing conflict: Citizenship education in high school social studies. Unpublished disseration / K. Bickmore. - California : Stanford University, 1991.

21. Fisher R. Unveiling the hidden curriculum in conflict resolution and peace education: Future directions toward a critical conflict education and conflict pedagogy / R. Fisher. - Vancouver, BC, Canada : Research Institute, 2000 .

22. Jaramillo N. Pedagogy of defiance: Public pedagogy as an act of unlearning. In J. Sandlin, B. Schultz, \& J. Burdick (Eds.). Handbook of public pedagogy: Education and learning beyond schooling / N. Jaramillo. - New York, NY : Routledge, 2010. - P. 500-510.

23. Graff G. Conflict pedagogy and student experience / G. Graff. - CCC, 1995. - P. 276-278.

24. Koshechko N.V. Actual ideas of pedagogical conflictology for preparation of educational professionals in domestic classical universities // Professional and pedagogical training of educational specialists in classical university of Ukraine: multi-authored monograph / Ed. by A. A. Marushkevich / N. V. Koshechko. - LAP LAMBERT Academic Publishing, 2019. - P. 89-110.

25. Kumashiro K. Troubling education: Queer activism and anti-oppressive pedagogy / K. Kumashiro. - London, UK : R-F, 2002.

26. Gutierez-Schmich T. Public Pedagogy and Conflict Pedagogy: Sites of Possibility for Anti-Oppressive Teacher Education. Electronic resource: https://scholarsbank.uoregon.edu/xmlui/bitstream/handle/1794/20 490/GutierezSchmich.pdf?sequence $=4$

\section{References}

1. Antonov H. V. Pedahohichni zasady zapobihannya i rozv"yazannya konfliktiv u navchal'no-vykhovnomu seredovyshchi vyshchoho navchal'noho zakladu : avtoref. dys. na zdobuttya nauk. stupenya kand. ped. nauk: spets. 13.00.04 teoriya i metodyka profesiynoyi osvity / H. V. Antonov - Kharkiv, 2006.

2. Bondarenko O.F. Psykholohichna dopomoha osobystosti O. F. Bondarenko. - Kharkiv : Folio, 1996.

3. Burlachuk L.F. Vvedenye v proektyvnuyu psykholohyyu I L. F. Burlachuk. - K. : Nyka-Tsentr, 1997.

4. Vashchenko I. V. Konfliktolohiya ta teoriya perehovoriv : navchal'nyy posibnyk / I. V. Vashchenko, M. I. Klyap. - K. : Znannya, 2013.

5. Haluzyak V. M. Pedahohichna konfliktolohiya : navchal'nyy posibnyk / V. M. Haluzyak, I. L. Kholkovs'ka. - Vinnytsya : "Nilan", 2015.

6. Hirnyk A. M. Osnovy konfliktolohiyi : navchal'nyy posibnyk / A. M. Hirnyk. - K. : Vyd-vo "Kyyevo-Mohylyans'ka akademiya", 2010.

7. Donchenko E. A. Lychnost'. Konflykt. Harmonyya / E. A. Donchenko, T. M. Tytarenko. - K. : Znanye, 1989

8. Dyurkgeym E. Samoubiystvo: Sotsiologicheskiy etyud ; per. s fr. s sokr. / pod red. V. A. Bazarova / E. Dyurkgeym. - M. : publishing house thought, 1994

9. Yenikeyeva D. D. Populyarnyye osnovy psikhiatrii / D. D. Yenikeyeva. Donetsk : Stalker, 1997

10. Kalina N. F. Osnovy psikhoterapii / N. F. Kalina. - M. : Vakler, 1996.

11. Kochyunas R. Osnovy psikhologicheskogo konsul'tirovaniya

R. Kochyunas. - M. : Akademicheskiy proyekt, 1999.

12. Mey R. Iskusstvo psikhologicheskogo konsul'tirovaniya / R. Mey. - M. Klas, 1994.

13. Menovshchikov V. YU. Vvedeniye $v$ psikhologicheskoye konsul'tirovaniye / V. YU. Menovshchikov. - M. : Smysl, 1998.

14. Rodzhers K. Kliyent-tsentrirovannaya terapiya / K. Rodzhers. - M. : Vakler, 1997

15. Semke V. YA. Umeyte vlastvovat' soboy, ili besedy o zdorovoy i bol'noy lichnosti / V. YA. Semke. - Novosibirsk : Publishing House "Thought", 1991.

16. Tutushkina M. K. Psikhologicheskaya pomoshch' i konsul'tirovaniye / M. K. Tutushkina. - Sankt-Peterburg : Didaktika Plyus, 1998.

17. Freyd Z. Vvedeniye v psikhoanaliz / Z. Freyd. - M. : Nauka, 1991.

18. Khorni K. Nashi vnutrenniye konflikty / K. Khorni. - Sankt-Peterburg : Lan', 1997.

19. Yurlov Yu. N. Intrapersonal conflicts of cadets of the higher military school and their resolution: Yurlov Yuri Nikolaevich. Intrapersonal conflicts of cadets of the higher military school and their resolution: Dis.... cand. psychol. Sciences: 19.00.14. - Moscow, 1996. RSL OD, 61: 97-19/98-7. 
20. Bickmore K. Practicing conflict: Citizenship education in high school social studies. Unpublished disseration / K. Bickmore. - California : Stanford University, 1991.

21. Fisher R. Unveiling the hidden curriculum in conflict resolution and peace education: Future directions toward a critical conflict education and conflict pedagogy / R. Fisher. - Vancouver, BC, Canada : Research Institute, 2000.

22. Jaramillo N. Pedagogy of defiance: Public pedagogy as an act of unlearning. In J. Sandlin, B. Schultz, \& J. Burdick (Eds.). Handbook of public pedagogy: Education and learning beyond schooling / N. Jaramillo. - New York, NY: Routledge, 2010. - P. 500-510.

23. Graff G. Conflict pedagogy and student experience / G. Graff. - SSS, 1995. - P. 276-278.
24. Koshechko N.V. Actual ideas of pedagogical conflictology for preparation of educational professionals in domestic classical universities // Professional and pedagogical training of educational specialists in classical university of Ukraine: multi-authored monograph / Ed. by Marushkevich A.A. / N. V. Koshechko. - LAP LAMBERT Academic Publishing, 2019. - P. 89-110.

25. Kumashiro K. Troubling education: Queer activism and anti-oppressive pedagogy / K. Kumashiro. - London, UK : R-F, 2002.

26. Gutierez-Schmich T. Public Pedagogy and Conflict Pedagogy: Sites of Possibility for Anti-Oppressive Teacher Education. Electronic resource: https://scholarsbank.uoregon.edu/xmlui/bitstream/handle/1794/20490/Gutier ezSchmich.pdf?sequence $=4$

Надійшла до редколегії 04.11.19

N. Koshechko, Ph.D, Associate Professor

Taras Shevchenko National University of Kyiv, Kyiv, Ukraine

\section{BASIC DIRECTLY OF PSYCHOLOGICAL CONSULTATION AT THE RESOLUTION OF THE INTERNAL CONFLICT STUDENTS AND TEACHERS: FOREIGN AND DOMESTIC EXPERIENCE}

The article analyses current ideas on the problem of resolving internal conflicts of students and teachers, which become the basis for pedagogical conflicts in higher education. Particular emphasis is placed on the resource capabilities of psychological counselling in resolving intrapersonal conflicts. Different psychological areas, schools provide specific definitions, structure, and dynamics of psychological counselling. But the main focus is on improving the effectiveness of psychological counselling and the client's well-being. The counselling process can range from one to a number of psychological sessions. The consequences of counselling can be considered in terms of changes in the client's personality and the degree of his satisfaction with the results of counselling. In this process, special attention is paid to the eclectic consultative conversation. Its content, characteristics, principles, specifics, stages, stages are considered in detail. The functions, purpose, procedure of counselling in higher education are summarized, which is interpreted as a dynamic process during which the teacher-consultant helps the student to use their internal resources to develop and actualize the potential of meaningful life. Consultative conversation - the subject of subjective interaction, which is built and maintained in a partnership style; the purpose of which is mutual enrichment of experience, self-development of both parties and solving student problems. Internal conflicts, which are resolved constructively, have a positive effect on the individual, ensure his further professional growth, and inspire faith in themselves and in people. Knowledge and basic competencies in the dynamics, specifics of internal conflicts can save time, maintain productivity, health, and increase creativity, professional, intellectual and personal competence of students, teachers and heads of higher education institutions. Destructively resolved conflicts have the opposite and can lead to neurosis, depression, affective states, mental illness, which, in turn, are the basis for other somatic diseases. That is why it is so important to resolve conflicts with a positive consequence, which is caused, in particular, by the appropriate tools of psychological counselling.

Keywords: psychological counseling, solving of personal conflicts, pedagogical conflicts, students, teachers.

УдК 378.124

DOI: https://doi.org/10.17721/2415-3699.2020.12.06

Н. Кузьменко, д-р пед. наук, доц. Київський національний університет імені Тараса Шевченка, Київ, Г. Варварецька, асист., Національний університет "Одеська морська академія", Одеса

\section{ІМІДЖ-ОБРАЗ ВИКЛАДАЧА ЗАКЛАДУ ВИЩОЇ ОСВІТИ ЯК СКЛАДОВА ПРОФЕСІЙНО-ПЕДАГОГІЧНОї КУЛЬТУРИ}

Зазначено, що сучасними тенденціями освіти є модернізація ії змісту, форм і методів, розробка й апробація нових освітньо-психологічних технологій, появою нових типів закладів освіти. Ці зміни, у свою чергу, залежать від постійної роботи керівника закладу освіти над іміджем своєї установи, власним іміджем і репутації науково-педагогічних працівників. Розглянуто найбільш вагомі складові, без яких формування позитивного іміджу викладача вищої школи не вбачається можливим. Виявлено, що одним із чинників формування позитивного іміджу майбутнього фрахівця є освітнє середовище закладу вищої освіти $і$, зокрема, вплив професорсько-викладацького складу. Проаналізовано роль іміджу викладача у формуванні професійних і особистісних якостей студентів. Визначено сутність поняття педагогічного іміджу, його формування й розвиток, функиії іміджу, структура особистісного іміджу. Це, зокрема, професійна компетентність, загальнолюдські цінності, норми моралі, управлінська культура та технологія самопрезентації. Наведено приклади впливу зовнішнього вигляду викладача на рівень засвоєння навчальної інформації студентами. Встановлено зв'язок між компонентами іміджу та складовими педагогічної майстерності викладача закладу вищої освіти, визначено взаємозумовленість позитивного іміджу педагога та його гуманістичної спрямованості. Зазначено шляхи формування позитивного іміджу викладача й розвитку педагогічної майстерності. Визначено типи іміджу, охарактеризовано кінетичний і мовленнєвий імідж. Обґрунтовано, що позитивний педагогічний імідж викладача здатен сприяти підвищенню ефективності педагогічної діяльності та формувати стиль соціальної поведінки викладача вищої школи. Проаналізовано дослідження з цієї проблеми й останні публікації вітчизняних і зарубіжних науковців.

Ключові слова: професійно-педагогічна культура, педагогічний імідж, функції іміджу, складові іміджу, типи іміджу, самопрезентація.

Постановка проблеми. У сучасних умовах педагогічної гуманістичної орієнтації висуваються нові вимоги до професійно-педагогічної культури викладача. Його здатність до продуктивної інноваційної діяльності обумовлюється не лише існуванням власної творчої лабораторії, а й набуттям індивідуалізованого стилю професійної поведінки, взаємодії зі студентами, колегами. Завдяки цьому формується певний імідж-образ педагога, який відображає його особливий внутрішній світ. Такий образ створюється відповідно до бачення педагогом манер професійної діяльності, педагогічного спілкування, зовнішнього вигляду й активно впливає на формування його профе-сійно-педагогічної культури. Викладачеві треба володіти спеціальними технологіями самопрезентації, індивідуалізації власного стилю роботи задля того, щоб досягти визнання, підвищити репутацію, зміцнити авторитет, переконати громадськість у доцільності й корисності своєї діяльності. Практичний досвід показує, що інтерес студентів до навчальної дисципліни залежить від особи викладача, від глибини професійних знань і ерудиції; 